\title{
Competence-based "Professional Foreign language" Educational Programs for Students of Economic Specialties: Ukrainian through European Dimension
}

\author{
A. O. Roliak
}

State Agrarian and Engineering University in Podillia, Kamianets-Podilskyi, Ukraine
Corresponding author. E-mail: rolyakangel@gmail.com

Paper received 30.01.20; Accepted for publication 15.02.20.

https://doi.org/10.31174/SEND-PP2020-221VIII89-03

\begin{abstract}
The research deals with the analysis of the content, structure and competence area of educational programs for students acquiring an economic specialty in the system of high education in Ukraine. The author grounds the main structural features, competence-based content with the necessary knowledge and skills of foreign language usage. The three major competencies areas: integral, general and special, - are characterized. The conducted study demonstrates that competency-based educational programs standardize English language teaching in high educational institutions of technical and economic profile.
\end{abstract}

Keywords: higher education, educational programs, competence-based, foreign language competence, knowledge, abilities.

Introduction. Foreign language competences are considered to be the main subject of change in the modern knowledge-based society and without progressive changes in the sphere of foreign languages teaching and learning it is impossible to transform society as a whole [12] We know that Ukraine is on the way of entering the European educational environment, so there is a demand for significant transition and substantial renewal throughout the whole system of its higher education, including the economic one. In order to provide the Ukrainian society with economists whose competencies would meet the requirements of the modern labor market, it is important to understand how professional training of economists must renovate.

A brief overview of publications on the topic. The definition of strategic directions for the development of the foreign language competences of students in economic specialties is of concern to the entire world community today. Recently there were appeared new studies of domestic scientists, connected with modern changes in the quality of education as a whole and the analysis of foreign experience in the professional training of economists. The article presents analytical materials of Ukrainian scientists: Petko L.V., Dyachenko L.M., Kotun K.V., Petiuh V.M., Bazyliuk B.H., Nicolaieva S.U., Honcharov V.I., Herasymenko O.O. and European scholars: Andreas Schleicher, Daniela Glocker, Viktor Steiner, Lawrence Reed, Ludwig von Mises, F.A. Hayek, Henry Hazlitt, and Hans Sennholz, etc.

The purpose of research. The major objective of this study is to investigate the structure and competence area of educational programs for students of economic specialties in the system of high education in Ukraine in the context of European education reforming in the early twentyfirst century.

Methods. Data for this study were collected using the systematic, synergetic, culturological, axiological approaches to the analysis of pedagogical phenomena. Basic information was gathered from multiple sources of European and Ukrainian environments at various time points from 2000 till 2020.

The systematic search of the European documents was conducted in three stages.

The first stage was "material collection". This stage included compellation of existing research data (in the Internet base) according to the object of the conducted study. The second stage was "selection and inclusion". The information was selected for its inclusion into the current study within the publication context, date limits, publication languages - English and Ukrainian. The third stage "synthesis completion" was conducted through both writing up and live-discussions of the research results and critical feedback from European and Ukrainian scholars.

Results and discussion. The purpose of teaching a foreign language course in a non-linguistic (technical) high educational institution is to develop the necessary competences in the fields of professional and situational communication in oral and written forms [1].

When we are speaking about the competence approach we mean the creation of a single system of aims, content, and technologies in the process of foreign language teaching and learning from the point of view of the formation of the basic professional competences [5]. So the competence approach in professional education makes it possible to outline the circle of important knowledge, abilities, and skills for the particular profession (economic in our research) and to give guidance for the educational program content on their mastering, developing and using in practical activities [7]. Moreover competence model of professional economic education of Ukraine can lead out Ukrainian specialists to the qualitatively new level, bringing their qualifications and degrees in correspondence with the European and world standards [9].

Our study demonstrates that in the European environment the term "competence" is an evaluative one. It denotes the ability of a specialist to use his or her knowledge and skills in practical professional activities [10]. Defining the European economic specialists' professional competences the most actual in new conditions of regional integration and development of the European knowledge-based community is the subject of an active discussion among educational specialists. It was considered that any European economist, first of all, must have deep subject knowledge in the sphere of specialization and professional competences to use the knowledge and skills efficiently [2].

Economists in European dimension work in a social context demanding, on one hand, the national identity and on the other transnational consciousness within the European community. So the "European dimension" became the important component of life-long education content. It should bring a balance between national and transnational 
values in the regional countries' educational policy. Judging from these facts we came to the conclusion that European economists (including Ukrainian) need foreign language competency as the basic component of their professional competences. As it is noted in European documents - European economists know more than one European language. Language skills he acquires in the system if life-long professional education. It would be very important for him to spend some period in a foreign environment to communicate with authentic language speakers $[6,11]$.

According to our analysis the main tasks of studying the discipline "Foreign language" for students of economic specialties in Ukrainian dimension are to acquire the skills of practical knowledge of a foreign language in different types of speech activity in the scope of topics due to professional needs; the use of oral monologue and dialogues in the context of domestic, socio-political and professional subjects; translation texts in the professional field from the foreign language into the native one [10].

The program is structured in a standardized for Ukraine way, consisting of 10 basic parts, compared with four major blocks of programs in basic European countries [4]. This division in the Ukrainian context may be the following:

1) the purpose of the discipline;

2) the discipline description;

3) the results of education;

4) evaluation criteria;

5) evaluation tools;

6) the discipline program;

7) themes of practical classes;

8) forms of current and final control;

9) tools, equipment, and software used in the academic discipline;

10) recommended sources of information.

In European countries the educational programs are mostly divided into four main blocks: 1) general discipline description; 2) the discipline program; 3) themes of practical classes; 4) forms of current and final control [4].

The content of the Ukrainian program "Foreign language for professional use" is competence-centered. Our research shows that there is no unified typology of economists' competence characteristics in Ukraine. This is the reason for existence of a large number of training programs in the Ukrainian system of professional education (each institute or university has a right to make its own curriculum, which must fulfill general strategic goals described by Ukrainian Laws on Education). In most cases, enumeration of the appropriate competencies in such study programs include references to European documents [6].

We investigated that standard programs content in the discipline includes the list of:

- the integral competence of an economist;

- $\quad$ the general competences; and

- the special competences.

So we continue our analysis taking into account these three fundamental competences areas.

Judging from the Ukrainian educational program, learning a foreign language in professional economic sphere ensures the development of the integral competence of a Bachelor of Economy specialty - the ability to solve complex specialized problems and practical problems in the field of Economy or in the course of study that involves the application of certain theories and methods of relevant science [3].

Moreover learning foreign languages in the economic context guarantees the development of the following general competences:

- ability to exercise the rights and duties as a member of a society, the awareness of the values of civil democratic society and the necessity of its sustainable development, the supremacy of law, rights and freedoms of citizens in Ukraine;

- ability to preserve moral, cultural, scientific values and increase the achievements of society through an understanding of the world history and patterns development of subject domain, its place in the general system of knowledge about nature and society;

- $\quad$ skills of oral and written professional communication in the state and foreign languages

- $\quad$ ability to apply knowledge in practical situations;

- ability to communicate in one of the foreign languages;

- ability to search, process and analyze information from various sources;

- $\quad$ ability to adapt and act in a new situation;

- $\quad$ ability to be critical and self-critical;

- ability to make substantial decisions;

- $\quad$ interpersonal team-work skills;

- ability to act as a socially responsible and conscious individual

As for the special professional competences of economists, foreign language knowledge makes it possible to enrich the ability to analyze in-depth problems and phenomena in one or more professional fields within the specialty in the worldwide environment.

The analysis of the "Professional Foreign language" programs for Students of Economic Specialties in the majority of the State Ukrainian technical universities provides an exciting opportunity to advance our knowledge of how the general program content is connected with the competence area development. So according to our survey, the basic topics of practical foreign languages lessons may be divided into two parts - everyday language, professional communication, and may include the following: introduction; working day; Ukraine; business trip; social life; healthy lifestyle; agrarian education (for the students of agricultural universities); the university; education in Ukraine and abroad (comparative aspect); profession; career; agriculture; Economics and economy; money; market types and market relations; international economy; trade; forms of ownership; etc. [10].

The "Professional Foreign language" program has the following learning outcomes:

1) to know the rules and norms of foreign business communication;

2) to be able to effectively communicate in foreign language orally and in writing - influence on the applicant's general educational results, and help to lead the educational trajectory into a proper direction [8]. Our study outlines that both the learning outcomes and program content together should bring to the development of the above-mentioned competence areas of economic specialties students. 
Conclusions. Overall, there seems to be some evidence to indicate that in the modern world being a highly qualified professional is challenging and there is an infinite number of areas in which economists can develop. Making decisions about what to focus on can be overwhelming for individuals. Foreign language communication competence is becoming the integral ability of every professional, working in the sphere of economics. Moreover in European countries recently new standards for specialists' professional level were established, bringing a signif- icant change in the way of professional competences conceptualization and implementation in almost all the European countries [1]. In the Ukrainian environment, competence-based educational programs will make economic education in this country more standardized. And as for a foreign language competence development in the professional dimension, it is inevitable that it ensures the development of the integral competence of a Bachelor of Economic specialty - the ability to solve complex specialized and practical problems in the field of economy.

\section{REFERENCES}

1. Bulavina O. Productive Economic Thinking - the Basis of Formation of Professional Competences of Students of the Specialty "Professional Education (Economics)" / Olena Bulavina//Professional Pedagogy. - 1(18). - 2019. - P. 180-186.

2. Hauschildt K. Social and Economic Conditions of Student Life in Europe / Kristina Hauschildt, Eva Maria Vogtle, Christophe Gwosc. - 2018. - German Centre for Higher Education Research and Science Studies (DZHW). - 284 p.

3. Heyne P. The Economic Way of Thinking / Paul Heyne, Peter Boettke, David Prychitko. $-13^{\text {th }}$ ed. $-2014 .-245$ p.

4. EUROPEAN dimensions of teacher education: similarities and differences / Milena Valenčič Zuljan and Janez Vogrinc [eds]. - Ljubljana: Faculty of Education ; Kranj: The National School of Leadership and Education, 2011. - 340 p.

5. European Commission. Key Data on Education in Europe / European Commission. - Luxembourg: European Commission, 2005. $-332 \mathrm{p}$.

6. OECD. Learning for Tomorrow's World: First Results from PISA 2003 / OECD. - Paris: OECD, 2004. - 471 p.

7. Ogienko O. Model of Professional Teachers Competences Formation: European Dimension//Ogienko O., Rolyak A.//TEPE 3rd Annual Conference Teacher Education Policy in Europe: Quality in Teacher Education, May 2009, Umea University, Sweden, Proceedings. - [Online]. - Available: http://tepe.wordpress.com/proceedings/tepe-2009-

proceedings.

8. Ogienko O. Humanization as the basic tendency of teacher education: European Context / Olena Ogienko, Angelina Rolyak//Education and Cultural change. - Helsinki, Finland (Network), 2010.

9. Roliak A.O. Reforms in teacher education system: Danish experience in Ukrainian environment//Humanities and Social Sciences in Europe: Achievements and Perspectives. The 1st International symposium proceedings. - 2018. - Berlin: Premier Publishing s.r.o.. - P. 70 - 78.

10. Roliak A.O. Foreign Language Competency Levels in Military Education / A.O. Roliak//Scientific Development of New Eastern Europe. Part 1. - Riga, Latvia: Baltija Publishing, 2019. - P. $62-65$.

11. Sprogøe J. Comparative analysis of lifelong learning strategies and their implementation in Denmark, Estonia, Finland, Iceland, Latvia, Lithuania, Norway, Sweden / Jonas Sprogøe. - 2003. - Copenhagen: The Danish University of Education. $-68 \mathrm{p}$.

12. The Lisbon Council. Policy Brief. The economics of knowledge: Why education is key for Europe's success / Andreas Schleicher [ed]. - Brussels: The Lisbon Council, 2006. $-20 \mathrm{p}$. 